ISSN : $2302-1590$

ECONOMICA

E-ISSN: $2460-190 X$

Jurnal Program Studi Pendidikan Ekonomi

STKIP PGRI Sumatera Barat Vol.9 No.2 (242-249)

\title{
ANALYSIS OF THE READINESS OF ECONOMICS TEACHERS IN FACING ONLINE LEARNING DURING
}

\author{
By \\ Sony Pratama' ${ }^{1)}$, Janah Sojanah ${ }^{2)}$, Abdul Rahmad ${ }^{3)}$ \\ ${ }^{1)}$ School of Postgraduate Studies, Universitas Pendidikan Indonesia \\ Email: 14sonypratama@upi.edu \\ ${ }^{2}$ School of Postgraduate Studies, Universitas Pendidikan Indonesia \\ Email: janahsojanah@gmail.com \\ ${ }^{3}$ School of Postgraduate Studies, Universitas Pendidikan Indonesia \\ Email: dulrahmad12@upi.edu
}

Submitted: 2020.11.23 Reviewed: 2021.04.19 Accepted: 2021.04.30

https://doi.org/10.22202/economica.2021.v9.i2.4519

\begin{abstract}
This study aims to describe the readiness of economics teachers to face online learning during the Covid-19 pandemic. This study uses a quantitative approach with an explanatory survey method. The research was conducted at Public Senior High Schools in East Belitung Regency involving 15 teachers spread across 5 schools. The data collection technique in this study used a survey technique with the Guttman scale. The results of this study indicate that the readiness of economic teachers to face online learning during the COVID-19 pandemic as a whole is in the ready category, which is $55.60 \%$, but when viewed from the eight indicators for indicators of teacher ability in planning and designing online learning designs and the ability to manage the learning system online, the teachers are not ready yet. Therefore, evaluation is still needed to improve teacher readiness in order to make online learning effective.

Jel Clasification:

I2; A2; D83

Keywords: Economics Teachers' Readiness, Online Learning, Covid-19 Pandemic
\end{abstract}

(C2021 Prodi Pendidikan Ekonomi STKIP PGRI, Padang 


\section{INTRODUCTION}

Teaching and learning activities in 2020 have undergone changes due to the global virus outbreak, namely Covid-19 which causes teaching and learning activities different from previous years (Yuli Tri Andini, 2020). As a result of the Covid-19 pandemic, it was recorded that in March 2020 more than 800 million students in the world learned at home (Oktawirawan, 2020). The Covid-19 pandemic has an impact on almost all aspects of life, including education (Syah, 2020). The Covid19 pandemic has eliminated all activities in Indonesia that have the potential to gather mass, including educational activities at all levels. As a result, almost all formal educational institutions organize online learning (Nahdi \& Jatisunda, 2020). This condition forces the stakeholder and observers of education design various methods of distance education, this is done so that education implementers have various alternative ways of providing students to learn (Ramanta \& Dwi Widayanti, 2020).

Online learning in the current situation is used as a solution during the Covid-19 pandemic (Dewi, 2020). This pandemic emergency condition requires the learning system be replaced with online learning so that the learning process continues, and this condition of course changes the learning pattern which requires teachers and educational developers to provide learning materials and teach students directly through remote digital tools (Fitriyani et al., 2020). The purpose of online learning or distance learning is to meet educational standards by utilizing information technology by using computers or gadgets that are connected between students and teachers and between students and lecturers so that through the use of these technologies the teaching and learning process can be carried out properly (Pakpahan \& Fitriani, 2020). Online learning can be defined as a teaching and learning activity that utilizes a network or internet connection so that there is communication between the teacher and students without involving physical contact (Loviana \& Baskara, 2020). Online learning is an educational innovation that involves elements of information technology in learning (Fitriyani et al., 2020). Online learning is also said to be learning which is carried out by utilizing an internet connection so that communication is established between educators and students without physical contact (Windhiyana, 2020).

Online learning in the current situation is indeed an alternative during the Covid-19 pandemic, but in its application, it is not as easy as thought. The obstacles experienced by teachers are that not all teachers have mastered the use of internet technology or social media as a means of online learning, some senior teachers have not fully mastered the use of tools or facilities to support online learning activities (Dewi, 2020). Face-to-face learning has several obstacles, but online learning also has its own set of obstacles and complex challenges (Naserly, 2020). The sudden shift in learning patterns from conventional (face-toface) to online has certainly caused various responses and obstacles to the education field in Indonesia, one of which feels it is the teacher who is known as the spearhead of education who is in direct contact with students (Henry Aditia Rigianti, 2020). Various problems that arise in online learning until now are still looking for solutions, the problems include weak signals, applications that often have problems and many other problems (Loviana \& Baskara, 2020). This condition of course has an impact on the quality of learning, teachers and students who previously interacted directly in the classroom are now forced to interact through a limited virtual space. Teachers are forced to provide good teaching, present conditions that are conducive to creative and innovative learning in utilizing learning media that are attractive to students, so that they can understand learning material and learning objectives can be achieved (Cahyani et al., 2020).

The use of technology in online learning 
practices is not without obstacles, there are various kinds of problems that hinder the effectiveness of learning using online methods, including: limited mastery of information technology by teachers and students, inadequate facilities and infrastructure, limited internet access, and inadequate budget provision (Syah, 2020). Obstacles in the application of online learning are also strengthened by a research conducted by $(\mathrm{Ni}$ Komag Suni Astini, 2019) who revealed that the Head of the Center for Information and Communication Technology for Education and Culture (Pustekkom) of the Ministry of Education and Culture (Kemendikbud) Gatot Suhartowo said that currently, from the total of teachers in Indonesia, there are only $40 \%$ who are information and communication technology (ICT) literate. The rest of them, $60 \%$ of teachers still stutter with progress in this digital era. There are three main causes, namely (1) the competence of teachers in Indonesia is very low in the field of ICT, 30 percent of those in Indonesia are over 45 years old, and even are about to enter retirement. (2) the content of educational technology is still minimal and (3). it is necessary to have adequate facilities and infrastructure in these areas. In Semarang City, $20 \%$ of elementary school teachers are still lacking in the use of IT (information technology) due to the age factor. Many of them are still confused on how to utilize IT. This fact proves that the low mastery of technology for teachers is a major problem that will have an impact on the success of online learning during this pandemic.

The problem faced by most of the teachers in dealing with the phenomenon of school from home/online is that the teachers are not ready to prepare learning models, methods and techniques that are suitable for distance education (Setiawan \& Rahman, 2020). Teachers who are the most important part of formal education are required to adapt to the implementation of learning which initially uses conventional face-to-face methods and switches to online learning (Ayu
\& Gunawan, 2020). Changes in learning and teaching patterns will certainly never be separated from the role of teachers, especially changes to online learning patterns, where teachers must be prepared for various learning conditions and student conditions, including the development of life in the community (Wahyono et al., 2020). For a teacher who is able to do face-to-face learning, this condition raises the unpreparedness of learning preparation (Henry Aditia Rigianti, 2020).

Teacher readiness is one of the determining factors for the success of online learning because teachers are directly in contact with students to provide guidance that will produce the expected graduates (Wardana, 2013). Teacher readiness is a condition that shows a sense of ready both physically and mentally in the form of knowledge and skills in carrying out his profession as a teacher in order to achieve predetermined goals (Septian Fuji Yama, 2016). Teacher readiness can also be said to be the key to the initial success of a lesson. The more mature the teacher's preparation in teaching, the greater the chance for students to get good learning results (Prabowo, 2011). In line with the statement about teacher readiness, (Hardianto, 2012) argues that the factors that influence teacher activity in teaching online includes having 8 abilities that must be mastered by an online learning educator, including: (1) mastering and updating internet development, (2) mastering basic and companion knowledge, (3) being creative and innovative in delivering and presenting material, (4) being able to motivate students to continue learning even though it is limited by distance and time, (5) being able to plan and design online learning, (6) being able to manage online learning systems, (7) being accurate in choosing teaching materials and online learning evaluation programs, (8) being able to control the learning process.

This research is in line with research conducted by (Ayuni et al., 2020) regarding the readiness of teachers to face learning during the COVID-19 pandemic. The difference 
between this study and previous research conducted by (Ayuni et al., 2020) lies in the type of research, which is located In this type of research, namely previous research using qualitative research types, while this research uses quantitative research types. In the research subject there are differences, previous research research subjects were kindergarten teachers while this study was on economics teachers. The purpose of this study was to obtain information about the readiness of economic teachers to face bold learning during the Covid 19 pandemic.

Based on some of aforesaid statements, they show that teacher readiness is very much needed in carrying out online learning during the Covid-19 pandemic, and the researchers focus on analyzing the readiness of economics teachers to face online learning during the Covid-19 pandemic. In addition, the purpose of this study is to obtain information on the digital literacy competence of economics teachers in facing online learning during the Covid-19 pandemic.

\section{METHODS}

The sampling technique used was saturated sampling. According to (Sugiyono, 2017), that: "saturated sampling technique is a sampling technique when all members of the population are used as samples". This is because the population used in this study is relatively small, less than 30 people or research that wants to make generalization with very little errors. So the sample studied was 15 economist teachers from East Belitung Regency. The place of research is in East
Belitung Regency.. This study is a quantitative research. The data were collected through an online explanatory survey where informants were asked to fill in several open-ended questions related to their experiences in conducting online learning to high school teachers in economic subjects in East Belitung district. The data obtained from the questionnaire were then analyzed using the Guttman scale measurement. The Guttman scale research is a study conducted to get a firm answer to a problem being asked, and it is always made in multiple choices, namely "yes and no", "right and wrong", or "positive and negative", for assessing the answers, for example a positive answer is given a score of 1 , while the negative answer is given a score of 0 , so if the answer to the question is ready to be given a score of 1 and not ready to be given a score of 0 , and if the score is converted into a percentage then logically it can be translated to agree answers, the score is $1=1 \times 100 \%=$ $100 \%$, and for disagree is given a score of $0=$ $0 \times 0 \%=0 \%$ (Iskani, 2013).

\section{RESULTS AND DISCUSSION}

This research was conducted by distributing questionnaires to 15 economics teachers spread across 15 schools in East Belitung district. The questionnaire contains 25 questions which are divided into 8 indicators about the readiness of economics teachers to face online learning during the Covid-19 pandemic. The results of the survey conducted through the questionnaire are described in the following diagram. 


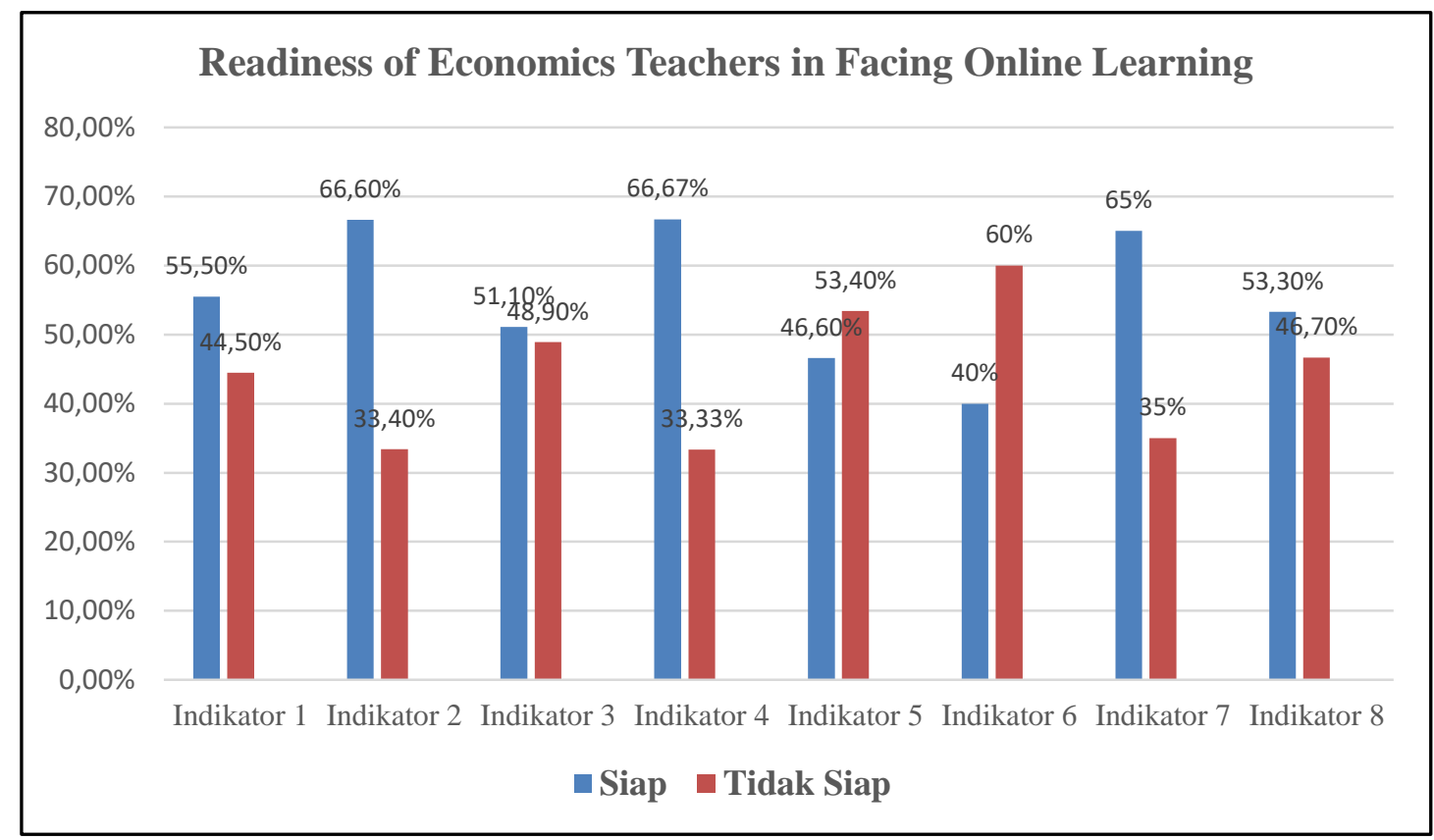

Figure 1. Results of the Economics Teachers' Readiness for Online Learning Questionnaire

Based on the diagram above, the first indicator is controlling and updating the development of the internet, which is $55.50 \%$. This fact shows that the majority of teachers are ready to use internet services and master various applications on computers to help them in the online learning process. Basically, teachers must be able to master and follow the development of technological advances. Because in online learning the teacher must be able to operate various types software and also hardware which is basically the basis that must be understood by teachers in online-based learning.

The second indicator is mastering basic and companion knowledge, which is $66.60 \%$. This result shows that the majority of teachers are ready to master learning material and are able to link learning with other relevant knowledge during online learning. Basically, the teacher must be able to master the basic knowledge of what will be conveyed, so that when the learning activity runs, if a problem occurs, it can be solved with logical thinking that the teacher understands. In addition, companion knowledge is also needed because during online learning a teacher is not only required to understand the material, but must have other observations.

The third indicator is creative and innovative in conveying and presenting the material, which is $51.10 \%$. This result shows that the majority of teachers are ready to deliver online learning materials creatively and innovatively, the respondents admit that they have been able to use various online learning media and are also able to provide real examples in explaining online learning materials. Basically, a teacher is required to have a creative and innovative spirit so that the learning material that will be delivered to students can be meaningful and also deep. Teachers who have high creativity will create a good impression for students so that they also feel unsaturated when learning activities take place. Teachers must also be able to continue to innovate in using online learning media, so that learning activities that take place are able to generate creativity and also the ability to think critically of students.

The fourth indicator is that the teacher is able to motivate students to continue learning even though it is limited by distance and time, which is $66.67 \%$. This fact shows that the majority of teachers are ready to provide motivation and encourage students to continue 
to excel even in the midst of this pandemic. Teachers are also able to foster enthusiasm in participating in online learning and remain enthusiastic in participating in learning even in the midst of limitations in both distance and time.

The fifth indicator is the teachers' ability in planning and designing online learning designs, which is $46.60 \%$. This result shows that the majority of teachers are not ready to plan and design various online learning designs, most teachers have not been able to make videos that are attractive to students and have not been able to design lesson plans according to online lesson plans.

The sixth indicator is the ability to manage the online learning learning system, which is $40 \%$. This result shows that the majority of teachers are not ready and do not understand the concept of online learning. The teacher has not been able to overcome if there are problems or problems with the LMS (Learning Management System) and video facilities conference like zoom, besmart, skype etc.

The seventh indicator is the accuracy of the teacher in the selection of teaching materials and the online learning evaluation program, which is $65 \%$. This fact shows that the majority of teachers are ready to develop online teaching materials and are also able to take reflective action after carrying out learning activities to improve the quality of learning.

The eighth indicator is the teacher's ability to control the net of the online learning process, which is $53.30 \%$. This result shows that the majority of teachers are ready to control online learning well, so that students' attention is focused on learning and classroom discipline is maintained and is also able to direct students to think critically in response to online learning.

\section{CONCLUSION}

Based on the results of data analysis that has been done previously, it can be concluded that from 8 indicators of economics teachers' readiness to face online learning during the Covid-19 pandemic, it shows an average score of $55.60 \%$ which is in the ready category. However, there are still two indicators that are in not ready category, namely the ability of teachers to plan and design online learning and the ability to manage online learning systems. This condition shows that there must still be an evaluation in carrying out this online learning activity, so that it can encourage the effectiveness of online learning and there is an increase in student learning outcomes in accordance with the expected goals.

\section{REFERENCES}

Cahyani, A., Listiana, I. D., \& Larasati, S. P. D. (2020). Motivasi Belajar Siswa SMA pada Pembelajaran Daring di Masa Pandemi Covid-19. IQ (Ilmu Al-Qur'an): Jurnal Pendidikan Islam, 3(01), 123-140. https://doi.org/10.37542/iq.v3i01.57

Dewi, W. A. F. (2020). Dampak COVID-19 terhadap Implementasi Pembelajaran Daring di Sekolah Dasar. Edukatif: Jurnal Ilmu Pendidikan, 2(1), 55-61. https://doi.org/10.31004/edukatif.v2i1.89

Fitriyani, Y., Fauzi, I., \& Sari, M. Z. (2020). Motivasi Belajar Mahasiswa Pada Pembelajaran Daring Selama Pandemik Covid-19. Profesi Pendidikan Dasar, 7(1), 121-132. https://doi.org/10.23917/ppd.v7i1.10973

Gunawan2, P. A. S. L. dan. (2020). The Impact of Covid-19 Pandemic on Learning Implementation of Primary and Secondary School Levels. 4(2), 189-199.

Hardianto, D. (2012). Karateristik Pendidik Dan Peserta Didik Dalam Pembelajaran Online. Majalah Ilmiah Pembelajaran, 8(2), 1-10.

Henry aditia rigianti. (2020). Kendala pembelajaran daring guru sekolah dasar di kabupaten banjarnegara. 21(1), 1-9. Https://doi.org/10.1155/2010/706872

Iskani. (2013). Pengukuran Skala Guttman Secara Tradisional (Cross-Sectional). Ejournal Poltektegal. 
Loviana, S., \& Baskara, W. N. (2020). Dampak pandemi covid-19 pada kesiapan pembelajaran tadris matematika IAIN Metro Lampung. Epsilon, 1(2), 61-70. https://doi.org/10.1017/CBO97811074153 24.004

Marlina, m., aliman, a., \& somantri, m. (2001). Komitmen dan motivasi kerja dalam meningkatkan kinerja guru marlina (sman 6 kota bengkulu), aliman (prodi map fkip unib), dan manap somantri (prodi map fkip unib).

Nahdi, D. S., \& Jatisunda, M. G. (2020). Analisis Literasi Digital Calon Guru Sd Dalam Pembelajaran Berbasis Virtual Classroom Di Masa Pandemi Covid-19. Jurnal Cakrawala Pendas, 6(2), 116-123. https://doi.org/10.31949/jcp.v6i2.2133

Naserly, M. K. (2020). Implementasi Zoom, Google Classroom, Dan Whatsapp Group Dalam Mendukung Pembelajaran Daring (Online) Pada Mata Kuliah Bahasa Inggris Lanjut. Journal of Chemical Information and Modeling, 4(2), 155-165. https://jurnal-

dikpora.jogjaprov.go.id/index.php/jurnalid eguru/article/view/129

Ni komag suni astini. (2019). Pentingnya literasi teknologi informasi dan komunikasi bagi guru sekolah dasar untuk menyiapkan generasi milenial. 2018, 113120.

Oktawirawan, D. H. (2020). Faktor Pemicu Kecemasan Siswa dalam Melakukan Pembelajaran Daring di Masa Pandemi Covid-19. Jurnal Ilmiah Universitas Batanghari Jambi, 20(2), 541. https://doi.org/10.33087/jiubj.v20i2.932

Pakpahan, r., \& fitriani, y. (2020). Analisa pemanfaatan teknologi informasi dalam pembelajaran jarak jauh di tengah pandemi VIRUS CORONA COVID-19. 4(2), 30-36.

Prabowo, A. E. (2011). Pengaruh Persepsi Dan Sikap Guru Terhadap Kesiapan Guru Mata Pelajaran Akuntansi Dalam Implementasi Ktsp Di Sma Negeri Se-
Kabupaten Blitar. Dinamika Pendidikan, 6(1), 26-34. https://doi.org/10.15294/dp.v6i1.5347

Ramanta, D., \& Dwi Widayanti, F. (2020). Pembelajaran Daring di Sekolah Menengah Kejuruan Putra Indonesia Malang pada Masa Pandemi COVID-19. Prosiding Seminar Bimbingan Dan Konseling, $\quad 0(0), \quad 61-67$. http://conference.um.ac.id/index.php/bk2/ article/view/81

Septian Fuji Yama, R. S. (2016). Pengaruh Pelatihan Guru, Kompetensi Guru Dan Pemanfaatan Sarana Prasarana Terhadap Kesiapan Guru Prodi Bisnis Manajemen Dalam Implementasi Kurikulum 2013. Economic Education Analysis Journal, 5(1), 1-1.

Setiawan, T. H., \& Rahman, A. N. (2020). Pelatihan daring teknologi pembelajaran. 01(01), 37-47.

Sugiyono. (2017). Metode Penelitian Kuantitatif, Kualitatif, dan $R \& D$. Bandung : Alfabeta, CV.

Syah, R. H. (2020). Dampak Covid-19 pada Pendidikan di Indonesia: Sekolah, Keterampilan, dan Proses Pembelajaran. SALAM: Jurnal Sosial Dan Budaya Syar$I$, $7(5)$. https://doi.org/10.15408/sjsbs.v7i5.15314

Wahyono, p., husamah, h., \& budi, a. S. (2020). Guru profesional di masa pandemi covid-19: review implementasi, tantangan, dan solusi pembelajaran daring. Jurnal pendidikan profesi guru, 1(1), 51-65. Https://doi.org/10.22219/jppg.v1i1.12462

Wardana, d. S. (2013). Motivasi berprestasi dengan kinerja guru yang sudah disertifikasi. Jurnal ilmiah psikologi terapan, $\quad$ 01(01), 98-109. Http://ejournal.umm.ac.id/index.php/jipt/a rticle/viewfile/1361/1456

Windhiyana, E. (2020). Dampak Covid-19 Terhadap Kegiatan Pembelajaran Online Di Perguruan Tinggi Kristen Di 248 Indonesia. Perspektif Ilmu Pendidikan, 
34(1),

https://doi.org/10.21009/pip.341.1

Yuli tri andini, m. D. W. (2020). Pelaksanaan pembelajaran daring pada masa pandemi covid-19 di tk bias yogyakarta. 4. 